\title{
Commentaries on "Choosing Our Futures"
}

These commentaries are responding to the article by Carla J. Stoffle, Robert Renaud, and Jerilyn R. Veldof on page 213 of this issue. They were selected to provide a diverse point of view.

\section{Change: But Not So Fast and Not So Much}

\section{Susan Lee}

As Carla Stoffle, Robert Renaud, and Jerilyn Veldof so rightly point out, the disagreement in the profession is not over whether academic libraries have to change, but over what, how, how fast, and how much change. They provide a comprehensive and rich discussion of the organizational elements, assumptions, and approaches that have to change. I take no issue with much of the what and how, or with the view that our libraries must initiate self-examination, focus on customers and their needs, emphasize continuous learning, and design new structures that are less hierarchical, more flexible, and more productive. My point of departure is with the how fast and how much. Librarians should draw on the authors' ideas, but must not be taken in by this corporate-model push for immediate revolutionary change.

As the authors' views are based on their experience at the University of Arizona Library, so my views are rooted in my experience at the Harvard College Library where we are in our sixth year of an organizational change effort. From that perspective let me say definitively that I firmly support the view (dismissed by the authors) that "for the foreseeable future, the library will essentially be dealing with traditional formats side by side with new technology." I say this recognizing that despite their common traditions, research libraries are diverse and the differences are real. The research libraries I speak for and about are our oldest research libraries serving subject areas in which a very small percentage of information is or soon will be electronic.

In addition, while research libraries certainly cannot confine themselves solely to print, the world of knowledge in the humanities and social sciences represented by these massive paper-based collections dictates a different approach to the future. "The challenge ... is not to replace the library as it has been with a virtual library.... We will not move from paper to bits. Rather the challenge is to integrate digital information into a massive paper-based collection."1

For these major research libraries to continue to support university research successfully, new strategies cannot and will not replace print collections or substitute for their ongoing development and maintenance. If anything, as so many libraries turn to access and away from ownership, these libraries will bear even greater collections responsibility. The greatness of these collections will not be diminished in a digital world. They will

Susan Lee is Associate Librarian of Harvard College for Administrative Services, Harvard University; e-mail: susan_lee@harvard.edu. 
not become museum objects. "Nothing could be farther from the truth. If anything, the vast historical print collections ... will become more and more valuable ... a unique resource for scholarship, only more valuable because more easily accessible." 2

\section{Reorientation Not Revolution}

The authors' call for radical change in the research library organization requires a complete break with the past and a major reconstruction of almost every element of the organization. From what they see as the demands of a life-threatening environment, they draw an imperative for fundamental organizational change. As they see it, our libraries and indeed all of higher education are in a situation where placing big bets is the only course of action. To do anything less is to risk organizational ruin. But "each new technological development is hyped by a chorus of prophets as the basis for evolutionary change in libraries.... and revolution is one of those strong words that has lost its impact in the field of technology because of overuse." ${ }^{13}$

And this fear-based revolutionary change is traumatic, painful, and demanding on the library organization, involving many people and a great deal of resources. It means that a certain degree of shock will be deliberately administered to the organization. It is a radical departure from the past and, therefore, carries with it all of the challenges associated with discontinuity. ${ }^{4}$ People, groups, and the whole organization not only have to learn new ways of thinking, working, and acting, they also have to "unlearn" the habits, orientations, assumptions, and routines that have been baked into the enterprise over time. And this unlearning will add to the difficulty and confusion. Their view of the current environment is one of fundamental crisis in which external conditions demand total change. The authors argue that there is not sufficient time for incremental change, not the luxury of time and opportunity to craft a long-term reorientation carefully. They call for the fast and simultaneous change of all the basic elements of the organizational system including a drastic shift in the library's core values. This kind of change necessarily involves the destruction of certain elements of the research library, the very elements that have been key to our success in the past.

While I wholeheartedly endorse the call for profound and far-reaching changes in our profession, I simply do not share the authors' sense of dire emergency. While our research libraries are indeed challenged, I believe that we can approach change as reorientation. We can and should build continuity with the past and take time to bring about the change. For many of us it is still early enough in the cycle of environmental change for a much more gradual organizational response. We have time to modify our libraries gradually, maintaining a degree of continuity with the past, while building on the best of the past. We can change, modify, and reshape our libraries without breaking them. We would be foolish to do anything more than reorientation when that is all that is needed. There is still time to build on the existing strengths of the libraries, including their rich history and traditions.

We can avoid breakage, trauma, and destruction. The changes must be as broad as the authors outline; however, done over time, we can reach the same goals without so much pain. Staff will need to change values, behavior, and thinking. But a more gradual approach will allow the opportunity for staff to learn and grow; and, given time and support, many of them will be able to change and function successfully in the new environment. Implicit in the authors' approach to systemwide change is the need for senior managers to act as key drivers, actively keeping the organization focused on the need for change. And while we must recognize the need for change and 
apply different types of change and different degrees of intensity, we would be foolish to ignore the authors' wake-up call. As they so correctly conclude, we must "change now and choose our futures." Because we have different pasts, we will choose different paths to different futures.

\section{Notes}

1. Sidney Verba, "Annual Report Draft," (Harvard University Library, January 1996).

2. Ibid.
3. Richard De Gennaro, "Keynote Introduction," (presented at the Finding Common Ground Conference, Harvard University, March 30, 1996).

4. David A. Nadler and Michael L. Tushman, "Types of Organizational Change: From Incremental Improvement to Discontinuous Transformation," in David A. Nadler, Robert B. Shaw, A. Elise Walton, and Assoc., Discontinuous Change: Leading Organizational Transformation (San Francisco: Jossey-Bass, 1994), 14-34.

\section{A Call to Arms}

\section{Bonnie Juergens}

For this respondent, the bottom line in commenting on "Choosing Our Futures" is the answer to two questions: (1) How accurate are Stoffle, Renaud, and Veldof in defining the current academic library environment and explicating the need for change in academic libraries? and (2) If they are on track, what are the implications for library service networks?

Because I have a career-long proclivity for seeking - and helping others find - the middle road on many topics and issues, it is difficult for me to admit that I agree with the extreme view held by the authors. Like those the authors describe as believing that "change ... will occur incrementally," I perceive major successes that past professional evolution, not revolution, has effected. Every fiber in my previously government-employed body strains to refute the urgency and magnitude of the behavioral and organizational changes called for by the authors. But that refutation is not forthcoming. I believe "Choosing Our Futures" is generally on target and deserves serious reflection and immediate action by all participants in our profession, not just those directly involved in the art and science of academic librarianship.
The authors say, "Work will undoubtedly change. What will stay the same is the constancy of purpose." They cite Jesse Shera's description of a librarian as one who "maximizes the social utility of graphic records." Articulated over thirty years ago, this definition of mission is even more relevant and has surprisingly up-to-date terminology today! The academic library's mission of supporting the research, education, and service purposes of the university remains valid. How we go about meeting the mission is what must change lest it become meaningless.

I find it hard to agree that print collections will disappear as fast as the authors intimate, and I am reminded that we have not yet identified long-term technologies to accommodate our paper-let alone electronic-archiving needs. I do agree that academic interlibrary lending, even to the tune of more than seven million titles per year, does not constitute resource-sharing "reaching its true potential."1 In general, I agree with the authors' thesis that change is urgently needed. And while there continues to be much discussion among members of our profession about the purpose, magnitude, type, and timeliness of change that is needed, nowhere have I seen it so radically stated as in "Choosing Our Futures." 
The remarks of these authors are sure to engender spirited disagreement. Some will ask what the authors' authority is for accusing higher education of losing credibility to the point of being seen as "part of the problem," for accusing the publishing and communications industries of being vultures waiting to pick the bones of a "weakened, declining educational industry," and for accusing faculty of remaining so steeped in denial and commitment to their status quo perks that public officials are angered and no longer find value in funding higher education. Phrases sure to raise hackles include: "needless complexity," "library staff bloat," "poor service," "[decision-making based on] subjective impressions and opinions," "isolation on campus and in the library worlds," "arrogant about our roles," "librarians have colluded," "interest in maintaining the status quo."

Yet, statements hard to dispute include: "We must change our traditional relationships and our view of competition," "It is vital that we develop win-win relationships with potential partners," "[Technological changes] have profound implications for teaching and learning, research, and institutional costs and competitiveness," "The competition for students and funding raised by the growing distance education option will force a reshaping of higher education," "Higher education cannot afford to utilize the technologies to do more with more, but must use and shape the results so that more is done with less."

The authors are calling for extensive reengineering, a restructuring of the way academic libraries do business. And although the authors' justification of the need for academic libraries to undergo fundamental, irreversible, and immediate change is primarily observational, it is supported by reports of corresponding pervasive change in private industry. As we read of "flattening" and "empowerment" and "teams," the most public ex- ample of change continues to be that of massive layoffs: job-cutting actions in the computer and telecommunications industries similar to earlier cuts in manufacturing, banking, and other private industries, along with the military, continue to make headlines. In the improving economy, job-cutting for productivity refinement appears to be ongoing:

Just when it looked as if job security might return with the recovering economy, corporate America has spoken loudly to the contrary. ... . Reasons for downsizing, though, have changed since the . . . [1991 American Management Association] poll. That year, nearly 75 percent of companies reduced staffs because of a business downturn. Today, ... productivity-enhancing measures such as improved staff utilization, transfer of work, and automation are greater downsizing factors. When maximizing productivity-rather than simply reducing payroll-is a primary reason for cutting staff, the effects on employee performance and business results are favorable. ${ }^{2}$

As librarians, we cannot pretend that such forces in the private sector don't apply to the library environment. Corporate decision-makers sit on public as well as private boards of institutions of higher education and bring the realities of private industry increasingly into management decisions about education. In short, whether the authors are correct in every detail of their diagnosis is irrelevant-it doesn't matter, because if even a small percent of today's higher education funding decision-makers agree, higher education has got to act. If libraries act while other proponents for change in this debate are still small in number, they will be seen as "proactive" and have a great opportunity for campus leadership. 
Those who delay or resist, trying valiantly to maintain the old while building the new, will be recognized as merely "reactive" when campuswide organizational changes finally come.

Librarians who direct or work in a library characterized by commitment to quality service; who are mission-oriented managers and information professionals who don't tolerate internal unit isolation and traditional "class" and "type-of-job" barriers; who enjoy a visible, highly interactive relationship with administrators, faculty, and students at all levels; and who have a long tradition of partnering with computer center(s), researchers, and other campus service providers can determine for themselves whether they need incremental or transformational change. Nevertheless, the factors below are driving some kind of change:

- "continuous improvement" demands it;

- new roles and service opportunities arise every day;

- technological change is relentless;

- the library staff has a need to be continuously learning (which means continuously changing);

- the more independently decisionoriented the staff becomes, the more they will introduce creative new ideas for service improvement;

- the more external relationships the library develops, the more opportunities will arise to introduce yet more change.

If "Choosing Our Futures" is on track, what are the implications for regional networking? For the past twenty years, networks such as AMIGOS have played a change-agent role by providing education and training for, and fostering professional inquiry among, librarians and paraprofessional staff. Member-governed networks that exist to serve and support libraries strive to provide affordable products and services that member librarians can utilize to serve their customers. Depending upon the strategic objectives set by those in network governance positions, the network supports or leads the membership to undertake new directions. Network support roles may include training in the evaluation, selection, and use of technology-based products, and facilitation of resource-sharing programs. Networks provide consultation on a wide range of technology and management topics and help foster interorganizational relationships. Network leadership roles may include direct or indirect support for research and development; library advocacy; and education for change adoption and change management.

If the governing boards of library service networks agree that radical change in libraries is needed, they must define the role of networks to be that of supporting or leading libraries to make those changes. A network whose role is to support change in libraries will limit its activities to assisting those members who seek such change. A network whose role is to provide leadership in transforming libraries will stake out a larger mission for itself: to identify the need for change in librarianship; to apply concurrent changes internally so that it supports the service orientation and restructured relationships it espouses; to educate its members about the need for change; and, finally, to find ways to assist all members, so that the full membership, not just the "leading edge" members, becomes better able to make this transformational leap into librarianship's future.

It is through dialogue with and the active involvement of members that library service networks identify the ways they can best serve their membership. "Choosing Our Futures" represents an important foundation for dialogue - and action-within our profession.

Author note: This commentary has been informed by discussions among senior managers at AMIGOS, both indirectly during the development of "Plan 2000: The AMIGOS Strategic Plan for 1995-2000" and directly in re- 
sponse to my request for reactions to the "Choosing Our Futures" article.

While retaining full responsibility for the opinions that are expressed herein, I wish to thank Robert Watkins, Cathy Wilt, and Barry Breen for their thought-provoking contributions.

\section{Notes}

1. Bonnie Juergens and Tim Prather, "The Resource Sharing Component of Access," Journal of Library Administration 20 (1994): 77-94, chart 2, p. 80.

2. "Downsizing Becomes the Norm," Performance: Management Strategies for Improving Productivity (Mar. 1995): 11.

\section{Changes and Continuities}

\section{Richard Hume Werking}

The origins of the modern college or university library in this country may be traced to the last quarter of the nineteenth century and the emergence of our current system of higher education. Ever since, the purpose of the academic library has been to make available the most relevant recorded information and knowledge to students, faculty, and others on behalf of research and study.

There are many elements of both continuity and change in how academic libraries have sought to accomplish their mission during the past century. One element of continuity has been the acquisition and organization for use of print-onpaper books, journals, and other graphic materials; another has been the library as a physical place, accommodating materials and people alike. Simultaneously, changes have occurred in how academic libraries and their parent institutions have worked to fulfill the libraries' mission as effectively as possible. Some of the more important changes over time have been: the professionalization of library staffs; the purchase of cataloging from the $\mathrm{Li}$ brary of Congress beginning in 1901; reference service; open stacks; microforms; consortia for resource sharing; photocopiers; OCLC; database-searching services; bibliographic instruction programs; integrated online library systems; commercial document-delivery services; $C D$ ROM databases; and electronic texts and data via the Internet. Many of the recent changes reflect developments in library automation and in electronic dissemination of information, which have made particularly noticeable differences. As Joanne Euster aptly observes, "A walk through today's college or university library reveals how it differs from the library of even a decade ago."1

Euster and Michael Buckland make the useful distinction between three kinds of libraries: paper, automated ("machinemanaged" paper), and electronic. They (among others) sensibly observe that libraries will continue to provide access both to paper and electronic documents simultaneously. ${ }^{2}$ At the Naval Academy's Nimitz Library, several local achievements in the last few months demonstrate the multifaceted world of academic librarianship in the late 1990s and for the foreseeable future, and the coexistence of different kinds of libraries within the same building. One achievement was the completion of a collection shift, resulting in thousands of volumes being moved from one floor to another and in the concomitant relocating of another 250,000 book and (unclassed) bound periodical volumes on the same floor. Another project was adding to our online catalog, and hence making available through the campus network, several tapeloaded periodical indexes. Other changes included the establishment of public workstations for accessing Web sites and other portions of the Internet, as well as adding a number of resource links to our homepage. 
More remarkable accomplishments than these are occurring daily in academic libraries. My point here is that each project, one extremely traditional and the others relatively newer to our practice, engaged the attention and talents of librarians who needed to manage it through to a successful conclusion. Such management of information resources on behalf of library users is central to what academic librarians have been about for a long time, and what they will need to be about for a long time to come. All librarians-administrators and nonadministrators alike-are really managers. They are managers of their own time, as well as of any specific projects on which they work. ${ }^{3}$

What our colleges and universities have needed and will continue to need, and what academic librarians should continue to provide, is the management of relevant information resources and services. Accomplishing this effectively and efficiently requires us to work closely with our users, to question our practices and assumptions, to identify the options carefully, and to choose thoughtfully and responsibly from among those options. It also requires our professional associations, through publications and other means, to promote study, research, and reflection into and about these important matters. And it behooves us to follow closely the developments at institutions which have chosen to be pioneers in one or more aspects of academic librarianship.

Consequently, I am perplexed by the opinion piece "Choosing Our Futures," which apparently is intended to serve as an advertisement for the next ACRL conference. It offers neither research findings nor detailed accounts of what has transpired at the University of Arizona (or elsewhere), but instead issues clarion calls to change. ${ }^{4}$ Change from what to what? Does it matter what a particular library may already be doing? Or is "radical, revolutionary organizational change" necessary for us all, whether our libraries are organized on the team model of the University of Arizona, or on a mixed model of traditional structure combined with working groups, or on some other organizing principle? Is it presumed that the organizational changes at the University of Arizona are in the "right" direction, as the authors imply, or should we take them seriously when they tell us that any change will do: "What we believe is that there will be many solutions and many paths to take. What is important is that we each take responsibility to choose our futures and act. In other words, just do it'"? As already noted, academic libraries have in fact changed markedly over the years, well in advance of this set of admonitions in which we are told some fifty times that librarians "must" do this, that, or another thing if we are to function effectively.

The authors are certainly correct that at least some aspects of higher education and scholarship are changing significantly. A recent news note from the Chronicle of Higher Education reports the formation by the National Association of State Universities and Land-Grant Colleges of "a commission to study what it called the 'crisis in higher education.'" It seems clear that colleges and universities, in contrast to their libraries, have changed relatively little in terms of how they do business. As more sweeping changes occur in higher education, our libraries will indeed need to adapt and change, as circumstances warrant, the means by which they accomplish their mission. Our track record is cause for some guarded optimism, though certainly not for complacency. And if we cannot or will not adapt in ways that we should, our institutions will find new ways of meeting their needs, as they certainly should. But let us look before we leap into any brave new world, by thinking first and organizing afterwards.

\section{Notes}

1. Joanne R. Euster, "The Academic Library: Its Place and Role in the Institution," in Gerard 
B. McCabe and Ruth J. Person, eds., Academic Libraries: Their Rationale and Role in American Higher Education (Westport, Conn.: Greenwood Pr., 1995): 4.

2. Ibid., 5; Walt Crawford and Michael Gorman, Future Libraries: Dreams, Madness, and Reality (Chicago, ALA, 1995), chapter 2 and p. 180.

3. I am indebted to Paul Mosher for this insight, which he was providing more than a dozen years ago.
4. The research content of ACRL conferences themselves has apparently declined since the first conference in 1978, perhaps reflecting a perception that research has little to offer practitioners of academic librarianship. See Pamela Snelson and S. Anita Talar, "Content Analysis of ACRL Conference Papers," College \& Research Libraries 52 (Sept. 1991): 466-72.

5. "Ways \& Means," Chronicle of Higher Education 42, no. 22 (February 9, 1996): A26.

\section{ACRL \\ PRESIDENT'S PROGRAM}

ALA Annual Conference, July 5-10, 1996, New York City

Saturday, July 6

"Every Librarian a

Leader"-Keynote

Address

Speaker: Dadie Perlov

An interactive session

covering:

- Academic institutions in transition

- Distance education

- The 21st-century leader

- Leadership roles, rights, and responsibilities

- Behavior styles

- Leadership myths
Sunday, July 7

New Strategies

for Creative

Approaches

Speaker: Mansfield

Elkind

A workshop-style

session covering:

- Developing creative problem-solving approaches

- Increasing understanding of existing skills

- Reviewing beliefs and developing new direction
Monday, July 8

Assessing Your Style Speaker: Dadie Perlov

A hands-on session covering:

- How other programs have addressed leadership issues

- Sharing leadership opportunities

- Furthering individual leadership plans

- Exploring principles of leadership in small-group discussion 